\title{
Motivación por oportunidad del emprendedor e internacionalización de la actividad de la Pyme
}

\author{
Antonia Mercedes García-Cabrera ${ }^{\mathrm{a}, 1}$, María Gracia García-Soto ${ }^{\mathrm{a}}$, Juan José Durán-Herrera ${ }^{\mathrm{b}}$ \\ ${ }^{a}$ Universidad de Las Palmas de Gran Canaria (ULPGC), España \\ ${ }^{b}$ Universidad Autónoma de Madrid, España
}

doi: $10.20420 /$ eni.2017.188

\begin{abstract}
Resumen
¿Condiciona la motivación emprendedora del fundador de una empresa las decisiones de internacionalización empresarial que éste adopta para su Pyme? Para responder a este interrogante, analizamos el caso de 296 emprendedores que han fundado sus empresas en Brasil. Los resultados indican que la motivación por oportunidad del individuo emprendedor condiciona la decisión de acometer operaciones internacionales, incluso años después de que éste haya fundado la empresa. Estos resultados apuntan hacia la necesidad de que los actores políticos no solo traten de fomentar la creación de más empresas, sino que acometan esfuerzos para generar un tipo particular de motivación emprendedora, esto es, la orientada a la búsqueda de oportunidades.
\end{abstract}

Palabras clave: internacionalización, emprendimiento, Pymes, motivación por oportunidad.

Clasificación JEL: L26, F23, M16.

Agradecimientos: Los autores agradecen el apoyo financiero proporcionado por el Ministerio de Economía y Competitividad (Proyectos: ECO2013-41762-P; ECO2016-80518-R).

Fuente de referencia: García-Cabrera, A.M., García-Soto, M.G., \& Durán-Herrera, J.J. (2016). Opportunity motivation and SME internationalisation in emerging countries: Evidence from entrepreneurs' perception of institutions. International Entrepreneurship and Management Journal, 12(3), 879-910.

\section{Introducción}

"Un emprendedor es un individuo que pone en marcha y dirige una empresa con el principal propósito de generar beneficios y crecimiento" (Carland y otros, 1984: 358). De esta forma, la definición de emprendimiento incluye tanto la responsabilidad de iniciar la actividad como, posteriormente, de asumir compromisos en la toma de decisiones (McClelland, 1961). De acuerdo con ello, el emprendimiento, como proyecto, puede ser considerado como un proceso que podría decaer con el tiempo en las empresas, por ejemplo tras experimentar el fundador ciertos fracasos al afrontar nuevos entornos tecnológicos (Alstete, 2002).

Por lo tanto, un factor clave para distinguir a los emprendedores de los propietarios-directivos de Pymes que no son emprendedores, es la preferencia de éstos por crear nuevas actividades, esto es, su voluntad para continuar encontrando nuevas combinaciones innovadoras de recursos, ofrecer éstas al mercado y con ello alcanzar beneficios crecientes a lo largo del tiempo. En otras palabras, se espera que los emprendedores identifiquen y exploten oportunidades empresariales a lo largo del tiempo, correspondiendo a éstos perseguir nuevas oportunidades que surjan "en cualquier industria y en cualquier momento" (Shane, Locke, \& Collins, 2003: 261). En este sentido, un emprendedor no circunscribe la puesta en marcha de proyectos exclusivamente al momento de establecimiento inicial de la empresa, sino que su fase creativa y de búsqueda de oportunidades de negocio la mantiene a lo largo del tiempo. Entre tales oportunidades, nosotros estamos interesados en las relacionadas con los mercados

${ }^{1}$ Autor de correspondencia: antonia.garcia@ulpgc.es 
exteriores, así como en las decisiones de internacionalización empresarial que éstas llevan aparejadas.

Se ha demostrado que los emprendedores ponen en marcha sus empresas por distintos motivos, entre ellos se encuentran los motivos llamada (pull motives) y los motivos empuje (push motives). Los primeros incluyen la búsqueda de rentas y riqueza, el reconocimiento o el deseo de alcanzar un elevado estatus. Los motivos empuje tienen que ver con el hecho de estar en desempleo y no poder acceder a un empleo por cuenta ajena, o bien por no hallar trabajo alguno que se corresponda con el nivel propio de formación. Si bien la distinción entre tales motivos es clara, no lo es tanto la influencia que éstos pueden tener en el comportamiento de los individuos en calidad de directivos de sus negocios (Dunkelberg y otros, 2013), entre ellos el relativo a las decisiones de internacionalización empresarial (Amorós, Basco, \& Romaní, 2016).

Como la motivación relaciona la agencia humana (esto es, la capacidad de la persona para tomar decisiones y para actuar con la intención de producir un efecto) con factores individuales que mueven al individuo hacia la acción (Deci \& Ryan, 1985), la motivación emprendedora es relevante para entender la evolución de las empresas. Por ejemplo, las motivaciones humanas influyen en las decisiones adoptadas tras el descubrimiento de oportunidades empresariales, de manera que las diferencias entre personas en lo que a motivación emprendedora se refiere tendrán una consecuencia en quienes decidan perseguir una determinada oportunidad emprendedora que han identificado (y quiénes no) y cómo van a llevar a cabo el proceso (Shane y otros, 2003).

Sobre la base de estas ideas, nuestro trabajo pretende ayudar a comprender la decisión de internacionalización empresarial que se adopta en una Pyme, partiendo de la premisa del papel relevante que el individuo, y su motivación, pueden tener en tal decisión. Más concretamente, el trabajo pretende responder al siguiente interrogante: ¿Qué papel juega la motivación por oportunidad del emprendedor en la decisión de internacionalización empresarial que tiene lugar en la Pyme?

\section{Motivación por oportunidad e internacionalización de la Pyme}

Los emprendedores son individuos que desean asumir responsabilidades, establecerse objetivos y alcanzarlos a través de su propio esfuerzo; individuos que desean sentirse libres para tomar sus propias decisiones (McClelland, 1965). Ahora bien, ello no es óbice para que existan emprendedores con motivaciones por oportunidad y emprendedores con motivaciones por necesidad.

La motivación por oportunidad existe en aquellos casos en los que el emprendedor se embarca en proyectos empresariales para explotar oportunidades de negocio, de manera que en alta medida se corresponden con el retrato de emprendedor que realiza McClelland (1965), más arriba comentado. El emprendimiento por oportunidad se produce cuando existen motivos llamada (pull factor) para fundar un negocio, tales como la búsqueda de rentas y riqueza, el reconocimiento y el deseo de alcanzar un elevado estatus, o la búsqueda de autonomía, esto es, razones relacionadas con la necesidad de logro y de independencia. Aunque las motivaciones no económicas (especialmente la independencia) son importantes en el emprendimiento por oportunidad, las de naturaleza financiera (resultados económicos) son claramente también un factor llamada.

El emprendimiento por necesidad, por su parte, se produce, cuando el desempleo empuja al individuo hacia el autoempleo (push motives), o bien cuando su familia y/o allegados están en paro y el emprendedor se ve obligado a 
emprender para generar un medio de vida a estas personas. La incapacidad para encontrar un empleo acorde al nivel de estudios que se posee también se considera un motivo empuje al emprendimiento por necesidad (Alstete, 2002).

La distinción entre emprendedores por oportunidad y por necesidad es pertinente ya que el emprendimiento por oportunidad difiere del de necesidad en las aspiraciones de crecimiento de los individuos para su proyecto empresarial (Acs, Desai, \& Hessels, 2008; Lecuna, Cohen, \& Chavez, 2017). En concreto, los emprendedores guiados por la oportunidad aspiran a que sus negocios alcancen ganancias elevadas, cuestión lógicamente relacionada con sus ambiciones de crecimiento (crecer para ganar más). Por ejemplo, la fuerte necesidad de logro de estas personas les conduce a implicarse en actividades innovadoras y exigentes, así como a preferir tareas que requieren elevadas habilidades y desarrollo de esfuerzo, pero que, al tiempo, ofrecen la oportunidad de alcanzar como contrapartida un elevado rendimiento (McClelland, 1965).

Ahora bien, aunque es ampliamente conocido que los emprendedores difieren en sus motivaciones para poner en marcha un negocio (relacionadas con la oportunidad y la necesidad), existen dudas sobre la importancia de tales motivaciones en lo que se refiere a su influencia en la forma en que el emprendedor dirige su negocio tras la puesta en marcha (Dunkelberg y otros, 2013). En este sentido, la motivación por oportunidad parece perseguir un conjunto de objetivos (ej., obtener elevadas ganancias, alcanzar reconocimiento y estatus social) que "llama" al emprendedor para que éste desarrolle proyectos empresariales de alto potencial de crecimiento (Acs, Desai, \& Hessels, 2008).

La expansión internacional es una forma idónea para alcanzar el alto crecimiento, de forma que el emprendedor con motivación por oportunidad podría estar más comprometido con la internacionalización que el emprendedor por necesidad. Por ejemplo, las personas con este espíritu emprendedor (por oportunidad) pueden tener una actitud permanente de búsqueda de oportunidades de negocio con altas perspectivas de crecimiento, siendo a este respecto la internacionalización empresarial una alternativa valiosa. De esta forma, la motivación por oportunidad puede incluso conducir al emprendedor a buscar oportunidades en el mercado doméstico como parte de un proceso de crecimiento paulatino que tiene lugar a lo largo del tiempo, para luego pasar a considerar la expansión internacional en cuanto se esté en disposición de afrontar el reto (ej., se han acumulado recursos económicos, de experiencia en la actividad).

Por otra parte, parece concebible que la motivación del emprendedor (de la persona) pueda afectar a la decisión de internacionalización que tiene lugar en la empresa (Madsen \& Servais, 1997; Lecuna y otros, 2017), porque los emprendedores normalmente centralizan la toma de decisiones en sus empresas, por ser éstas habitualmente de pequeño o mediano tamaño (Pymes) y con escaso desarrollo de la estructura organizativa (Cheng \& Yu, 2008). De esta forma, es posible que la motivación del emprendedor se materialice en las acciones que acomete la empresa, que a este respecto y en cierta medida puede considerarse una proyección de la persona. Además, aunque el emprendedor requiera de la cooperación de los empleados para implantar sus decisiones en materia de internacionalización, puede ser relativamente sencillo para él lograr tal cooperación si difunde entre sus empleados sus percepciones y juicios personales al respecto de la decisión. La proximidad entre el propietario-directivo de una Pyme y sus empleados facilita una conexión directa, personal y cercana entre ellos. De esta forma, con la comunicación de sus percepciones y juicios, el emprendedor puede generar un 
consenso entre sus colaboradores y crear una suerte de unanimidad en la percepción de las perspectivas y retos a afrontar por la empresa (Casson, 2005).

De acuerdo a lo aquí presentado, puede esperarse que cuanto mayor sea la motivación por oportunidad del emprendedor, mayor sea la probabilidad de que el individuo implique a su empresa en operaciones de expansión internacional.

\section{Metodología}

Al objeto de testar las ideas antes mencionadas llevamos a cabo un estudio empírico en Brasil, concretamente en el Estado Federal de Sergipe. Brasil es una economía emergente que se ha caracterizado por la creciente internacionalización de sus Pymes y grandes empresas.

En concreto, el trabajo realizado se centra en la industria turística porque ésta representa un sector estratégico para el desarrollo de muchos países (Liu \& Wall, 2006). La industria turística representa más del $5 \%$ de la actividad económica mundial y es la cuarta industria en tamaño tras la petrolífera, la química y la del automóvil (UNWTO, 2011). El sector turístico, en la actualidad, está contribuyendo a la internacionalización de la economía de los países mediante la actividad que realizan en el extranjero las empresas del sector, entre ellas las cadenas hoteleras o los turoperadores, así como numerosas Pymes cuyas actividades empresariales giran en torno a la organización de actividades de recreación y ocio (ej., submarinismo), las consultoras especializadas en arquitectura para hoteles, etc. De esta forma, aunque la internacionalización puede parecer una actividad extraña para los negocios turísticos, las empresas turísticas se expanden internacionalmente hacia otros países.

En este contexto, en este trabajo analizamos el caso de 296 emprendedores localizados en seis municipios turísticos del Estado de Sergipe, en
Brasil (Aracaju, Pirambu, São Cristóvão, Laranjeiras, Canindé de São Francisco y Estância), y que cumplían con los siguientes requisitos: eran fundadores, propietarios y directivos de una Pyme (entre 10 y 250 empleados) que operaba en el sector turístico, llevando a cabo actividades tales como hostelería, restauración, actividades de ocio y recreación o de intermediación turística (turoperadores).

\section{Procedimiento y resultados}

Centrándonos en el momento de puesta en marcha de la empresa, se preguntó a los emprendedores por su motivación para emprender. En concreto, se les preguntó si habían iniciado la actividad por razones tales como su voluntad de explotar oportunidades empresariales, ganar mucho dinero, explotar las habilidades que tenían como emprendedor, o sacar provecho de su nivel educativo, entre otras, esto es, razones relacionadas con la motivación por oportunidad. También se preguntó por la expansión internacional de su Pyme, pidiéndoles que indicaran si la empresa estaba activamente comprometida en el desarrollo de operaciones internacionales en el momento en el que se estaba llevando a cabo el trabajo empírico. A este respecto, nos aseguramos de que la decisión de internacionalización estaba siendo adoptada y desarrollada por el emprendedor que había fundado la empresa; en otro caso el cuestionario no se consideraba válido.

Las Pymes creadas por los emprendedores participantes en el estudio tenían un tiempo medio de vida de 9,89 años, de forma que éste es el tiempo que, en promedio, ha trascurrido desde la puesta en marcha de la empresa hasta el momento en el que se lleva a cabo el trabajo empírico. Por otra parte, 75 emprendedores participantes en el estudio tenían un nivel alto de motivación emprendedora, mientras que 86 poseían un nivel medio y los restantes 135 individuos un nivel bajo o muy bajo. De estos 
135 emprendedores, 20 habían internacionalizado su empresa, en concreto 1 del grupo que contaba con muy baja motivación por oportunidad y los 19 restantes del grupo con bajo nivel de esta motivación.

Los análisis realizados sobre la base de la información recabada demuestran que la motivación del emprendedor en el momento de la puesta en marcha de la empresa determina la decisión de expansión internacional de esta, incluso trascurridos años tras la puesta en marcha de la misma. En otras palabras, los resultados encuentran que cuanto mayor es la motivación por oportunidad del emprendedor en el momento en el que puso en marcha su empresa, más probable es que tal individuo implique a su empresa en operaciones de expansión internacional a lo largo de la vida de la empresa. Por consiguiente, la motivación por oportunidad es altamente relevante para el crecimiento de los negocios y para las expectativas de generación de riqueza y empleo a lo largo del tiempo. En términos agregados, ello puede tener un impacto elevado para el desarrollo económico de los países.

\section{Conclusiones}

Como conclusión de este trabajo puede indicarse que la motivación por oportunidad del emprendedor no solo afecta a las decisiones tomadas por éste en el momento de puesta en marcha de su empresa, como se ha venido resaltando, sino que también tiene un efecto relevante con posterioridad en el tiempo, a lo largo de la trayectoria de la empresa. En concreto, nosotros hemos encontrado este efecto para el caso de las oportunidades de negocio internacional identificadas a lo largo de la vida de la empresa, condicionando la motivación inicial del emprendedor las decisiones que éste adopta respecto a la internacionalización de la misma.
De esta conclusión deriva una importante implicación práctica para las autoridades locales, regionales y nacionales. El trabajo sugiere que para que el emprendimiento sea capaz de generar tasas mayores de riqueza y empleo, los emprendedores deben contar con motivaciones emprendedoras. Como consecuencia, parece lógico que las autoridades, además de realizar esfuerzos para estimular la creación de más empresas en sus territorios, promuevan un tipo particular de motivación en los emprendedores, esto es, la motivación por oportunidad.

Esta motivación podría ser incentivada desde la infancia, esto es, desde los niveles de educación primaria y hasta alcanzar la educación universitaria, generando así una cultura proclive al emprendimiento por oportunidad. Además, parece probable que aquellos individuos que perciban un entorno que ofrece la oportunidad de iniciar proyectos empresariales con perspectivas de alto crecimiento podrían, como consecuencia, reconocer su propia motivación por oportunidad, tal vez latente $\mathrm{o}$ hasta ese momento imperceptible para ellos, al verse atraídos hacia estos entornos. De hecho, se ha demostrado que la motivación por oportunidad abunda en contextos económicos caracterizados por marcos institucionales que favorecen la actividad expansiva de las empresas, mientras que la motivación por necesidad predomina en países con entornos institucionales débiles, tales como las economías en desarrollo (Acs \& Amorós, 2008). Por ejemplo, un marco legislativo estable que apoye e incentive la internacionalización, puede motivar a los emprendedores a buscar oportunidades de negocios en otros países, ya que tales esfuerzos no corren el riesgo de verse frustrados como consecuencia de posibles discontinuidades y cambios de rumbo del marco regulativo del país (Volchek, Saarenketo, \& Jantunen, 2015). Finamente, la existencia de modelos de negocio de alto crecimiento y éxito internacional ampliamente conocidos, así como la disponibilidad de conocimiento especializado 
en la región podría también generar motivación hacia la búsqueda de oportunidades de negocio internacionales (Acs, Desai, \& Hessels, 2008), por ejemplo, por contar la población con manejo de idiomas, con experiencia en multinacionales y conocimiento sobre cómo funcionan los negocios en otros países.

Corresponde, por tanto, a los gobiernos generar las condiciones culturales, legislativas y educativas, entre otras, con capacidad para generar motivación emprendedora por oportunidad en la población. Los resultados del presente trabajo invitan a que ello se acometa.

\section{Referencias}

Acs, Z.J., \& Amorós, J.E. (2008). Entrepreneurship and competitiveness dynamics in Latin America. Small Business Economics, 3, 305-322.

Acs, Z.J., Desai, S., \& Hessels, J. (2008). Entrepreneurship, economic development and institutions. Small Business Economics, 31, 219-234.

Alstete, J.W. (2002). On becoming an entrepreneur: An evolving typology. International Journal of Entrepreneurial Behaviour and Research, 8(4), 222234.

Amorós, J.E., Basco, R., \& Romaní, G. (2016). Determinants of early internationalization of new firms: the case of Chile. International Entrepreneurship and Management Journal, 12(1), 283-307.

Carland, J.W., Hoy, F., Boulton, W.R., \& Carland, J.A.C. (1984). Differentiating entrepreneurs from small business owners: A conceptualization. Academy of Management Review, 9(2), 354-359.

Casson, M. (2005). Entrepreneurship and the theory of the firm. Journal of Economic Behavior \& Organization, 58, 327-348.
Cheng, H.L., \& Yu, C.M.J. (2008). Institutional pressures and initiation of internationalization: Evidence from Taiwanese small and medium-sized enterprises. International Business Review, 17, 331348.

Deci, E.L., \& Ryan, R.M. (1985). Intrinsic Motivation and Self-Determination in Human Behaviour. New York: Plenum Press.

Dunkelberg, W., Moore, C., Scott, J., \& Stull, W. (2013). Do entrepreneurial goals matter? Resource allocation in new owner-managed firms. Journal of Business Venturing, 28, 225-240.

Lecuna, A., Cohen, B., \& Chavez, R. (2017). Characteristics of high-growth entrepreneurs in Latin America. International Entrepreneurship and Management Journal, 13(1), 141-159.

Liu, A., \& Wall, G. (2006). Planning tourism employment: a developing country perspective. Tourism Management, 27, 159-170.

Madsen, T.K., \& Servais, P. (1997). The internationalization of born globals: An evolutionary process? International Business Review, 6(6), 561583.

McClelland, D.C. (1961). The achieving society. Princeton, NJ: Van Nostrand.

Shane, S., Locke, E.A., \& Collins, C.J. (2003). Entrepreneurial motivation. Human Resource Management Review, 13(2), 257-279.

UNWTO. Barometer of The World Tourism Organization (UNWTO). Retrieved from http://www.unwto.org.

Volchek, D., Saarenketo, S., \& Jantunen, A. (2015). "Structural model of institutional environment influence on international entrepreneurship in emerging economies", In Institutional impacts on firm internationalization, ed. S. Marinova, London, UK: Palgrave MacMillan, pp. 190-216. 


\title{
Opportunity motivation of entrepreneur and SME's internationalization
}

\author{
Antonia Mercedes García-Cabrera ${ }^{\mathrm{a}, 1}$, María Gracia García-Soto ${ }^{\mathrm{a}}$, Juan José Durán-Herrera ${ }^{\mathrm{b}}$ \\ ${ }^{a}$ Universidad de Las Palmas de Gran Canaria (ULPGC), Spain \\ ${ }^{b}$ Universidad Autónoma de Madrid, Spain
}

\begin{abstract}
What role does entrepreneurial motivation of founders play in the internationalisation decision of SMEs? To answer this question, we analyse a sample of 296 entrepreneurs who had founded their businesses in Brazil, and our results suggest that the individual's opportunity motivation conditions the decision to embark on international operations in SMEs even years after of having started-up the business. These results point to the need for authorities not only encourage an increasing number of new ventures, but also the need for making efforts to generate a particular category of entrepreneurial motivation, that is, the opportunity motivation.
\end{abstract}

Keywords: Internationalisation, entrepreneurship, SMEs, opportunity motivation.

JEL classification: L26, F23, M16.

Acknowledgements: Financial support from the Spanish Ministry of Economy and Competitiveness (Projects: ECO201341762-P; ECO2016-80518-R) is gratefully acknowledged.

Reference source: García-Cabrera, A.M., García-Soto, M.G., \& Durán-Herrera, J.J. (2016). Opportunity motivation and SME internationalisation in emerging countries: Evidence from entrepreneurs' perception of institutions. International Entrepreneurship and Management Journal, 12(3), 879-910.

\section{Introduction}

"An entrepreneur is an individual who establishes and manages a business for the principal purposes of profit and growth" (Carland and others, 1984:358). So, the definition of entrepreneurship should centre around the responsibilities of initiating and later on being responsible for business decisions (McClelland, 1961). Accordingly, entrepreneurship, as a project, can be seen as a process, which may decline in new ventures, for example, after certain failures in a new technological environment (Alstete, 2002).

Therefore, a key factor to distinguish between entrepreneurs and non-entrepreneurial SMEs' owners-managers is the preference for creating activity, that is, their will to find some innovative combination of resources for profit over time, not only at the time of starting-up their business. Entrepreneurs are expected to identify and exploit business opportunities over time as they can pursue emerging opportunities in any industry "at any time" (Shane, Locke, \& Collins, 2003:261). Among them, we are interested on international opportunities and the internationalization decision.

Previous studies on entrepreneurship shows that entrepreneurs have different motives to startup a business, among them both pull motives (e.g., income and wealth, recognition and status) and push motives (e.g., unemployment). However, it is not clear the influence these motives may have on these individuals' behaviour as managers of their businesses (Dunkelberg and others, 2013), among them

${ }^{1}$ Corresponding author: antonia.garcia@ulpgc.es 
those related to internationalization decision (Amorós, Basco \& Romaní, 2016).

As motivation relates the nature of human agency to factors that generate action (Deci \& Ryan, 1985), the entrepreneurial motivation is quite relevant for the business evolution. For example, human motivations influence decisions made after the discovery of opportunities, so that the variance across people in entrepreneurial motivations will influence whoever pursues entrepreneurial opportunities and how they undertake the entrepreneurial process (Shane, Locke, \& Collins, 2003).

Based on the above, the current study aims at understanding the internationalisation decision in SMEs while accepting the important role of the individual. Specifically, we aim at answering to the following research question: What role does opportunity motivation of entrepreneurs play in the internationalisation decision of the SME?

\section{Opportunity motivation and SME internationalisation}

Entrepreneurs are individuals desiring to assume responsibilities, to set themselves goals and to achieve them through their own efforts; individuals wishing to feel free to make their own decisions (McClelland, 1965). However, we can commonly find entrepreneurs with opportunity and necessity motivations.

Opportunity motivations apply to those cases where the entrepreneur embarks on business projects to exploit business opportunities and so highly corresponding with McClelland's (1965) portrayal. Opportunity entrepreneurship implies pull motives to start up a venture such as income and wealth, recognition and status or autonomy and independence, that is, reasons related to the need for achievement and the need for independence. Although non-economic concerns (especially independence as a relevant factor) are important in opportunity entrepreneurship, financial (performance) concerns are also relevant as a pull factor.

Necessity entrepreneurship occurs, for example, when unemployment pushes people into self-employment - i.e., push motives (Alstete, 2002).

The distinction between opportunity and necessity entrepreneurs is pertinent as opportunity differs from necessity entrepreneurship in the growth aspirations of the business project (Acs, Desai, \& Hessels, 2008; Lecuna, Cohen \& Chavez, 2017). In particular, opportunity-driven entrepreneurs expect their ventures to reach higher income, which is usually positively related to their ambitions for growth. For example, the intense need for achievement of these people leads them to engage in energetic and innovative activities and to prefer tasks that involve skill and effort, and provide clear performance feedback (McClelland, 1965).

Although is well known that entrepreneurs have different motivations to start-up a business (e.g., related to opportunities, necessity), doubts exist about the importance of such motivations in how these individuals run their businesses (Dunkelberg and others, 2013). In this respect, opportunity motivation seems to embrace a set of objectives (e.g., obtaining a high income, reaching a high social status) that "pulls" the entrepreneur towards the implementation of business projects with high growth potential (Acs, Desai, \& Hessels, 2008).

International operations are the ideal way of achieving such growth, so entrepreneurs with opportunity motivation will conceivably be more committed to internationalisation. For example, people with entrepreneurship endowment (spirit) may have, in general, an attitude for searching out opportunities for new business with growth perspectives where internationalisation is a 
possibility. Then opportunity motivation may lead to searching for domestic business growth and, as a consequence of a process -as entrepreneurship must be understood (Shane, Locke, \& Collins, 2003)-, to considering the possibilities of international expansion. Hence, motivation may be considered as a "pull category factor".

In addition, entrepreneurs' motivations will conceivably affect the internationalisation decision (Madsen \& Servais, 1997; Lecuna and others, 2017), as we propose, because entrepreneurs usually centralise the decisionmaking in SMEs because of the low level of organisational structure in such firms (Cheng \& $\mathrm{Yu}, 2008)$, so it is possible that their motivations materialise in their firms' actions. Furthermore, although entrepreneurs require the cooperation of employees to implement their decisions, they can reach this cooperation by disseminating information about their perceptions and judgements. In doing so, they can build a consensus among their collaborators by creating unanimity of perception about the firms' prospects (Casson, 2005).

Accordingly, we can expect that the greater the entrepreneur's opportunity motivation, the more likely this individual will involve their SME in international expansion operations.

\section{Methodology}

For checking the previous expectation, we carried out an empirical study in Brazil (Federal State of Sergipe), an emerging economy that has seen increasing internationalisation in its SMEs.

Our work looks at the tourism industry because it is a strategic sector in the socioeconomic development of many countries (Liu \& Wall, 2006). The tourism industry accounts for more than 5 percent of worldwide economic activity and is the fourth biggest industry after fuel, chemicals and automotive (UNWTO,
2011). In addition, the tourism industry can increase firm internationalisation in a country via the foreign activity of firms such as hotel chains and tour operators, but also other SMEs such as those that organise recreational activities (e.g., scuba diving), tourism consultants in specialised architecture for hotels, etc. So, although internationalisation may seem a strange activity for a tourist business, tourist firms are internationally expanding toward other countries.

Accordingly, we analysed a sample of 296 entrepreneurs who were located in the six tourist municipalities of the state of Sergipe (Brazil) Aracaju, Pirambu, São Cristóvão, Laranjeiras, Canindé de São Francisco, and Estância- and fulfilled the following preconditions: they are founders, owners and managers of an SME operating in a tourism-related sector, for example, hotel and catering, recreational activities, or tour operators.

\section{Procedure and results}

We asked entrepreneurs for their opportunity motivation at the moment of starting up the firm (reasons such as their will to exploit business opportunities, make lots of money, exploit skills as entrepreneur, the chance to make use of their own educational level). We also questioned them about the SME's International expansion requiring them to indicate if the SME was actively committed to international operations at the moment of carried out the empirical work. We assured that the internationalisation decision was made by the entrepreneur that had started-up the firm in order to consider the questionnaire as valid.

The sample firms have a mean age of 9.89 years, so this is the time that have passed on average from the started up of the business and the time the empirical work was carried out. While 75 entrepreneurs in the sample have a high level of opportunity motivation, 86 have a 
medium level, and 135 entrepreneurs have a very low or low opportunity motivation. In addition, 20 out of the 135 entrepreneurs with very low (1 participant) or low opportunity motivation (19 participants) have involved their SMEs in international expansion operations.

Results show a positive and significant influence of entrepreneurs' opportunity motivation on the decision to expand internationally. In other words, results find that the greater the entrepreneur's opportunity motivation at the time of starting-up the business, the more likely this individual will involve their SME in international expansion operations years after the firm was started-up. So, opportunity motivation is quite relevant for the growth of businesses and the expectations about generation of wealth and employment over time. Considering this finding at an aggregate level, it can have a high impact on the economic development of countries.

\section{Conclusions}

Our work expands upon the of previous research, finding that opportunity motivation affects the decisions made by the firm's entrepreneur at the start-up stage, in that it finds that this effect is also evident later on. Specifically, when the entrepreneur identifies new opportunities related to the internationalisation of their firm later in its life.

This conclusion has an important practical implication. Specifically, results suggest that in order for business ventures to be able to generate wealth and employment in their countries/regions, local and national authorities not only should concentrate on the number of firms created, but also it is essential to promote a particular type of motivation in the entrepreneurs, the opportunity motivation.

Opportunity motivation should be incentivised from the first levels of educations at primary school till higher education, and so generate it as a culture, due to the relevance for the economic development of a country. In addition, it seems likely that those individuals who perceive an environment that offers them the chance to set business projects with highgrowth perspectives could recognise their own latent opportunity motivation, and so be attracted to and perform well in these environments. Specifically, previous research associates opportunity motivation with economic contexts characterised by developed institutional frameworks that are favourable to expansive business activities, and necessity motivation with countries characterised by weak institutional frameworks, such as the emerging economies (Acs \& Amorós, 2008). For example, a supportive and stable domestic regulatory framework (e.g., stimuli to internationalization) may motivate entrepreneurs to seek out international opportunities, as the firms' resources would not be wasted by the regulative local discontinuances (Volchek, Saarenketo, \& Jantunen, 2015). Finally, the existence of business models of growth and success and the availability of specialised knowledge in the country/region may also generate the entrepreneurial motivation to seek out international opportunities (Acs, Desai, \& Hessels, 2008).

It is therefore up to the governments to generate cultural, legislative and educational conditions, among others, with the capacity to generate entrepreneurial opportunity motivation in the population. The results of the present work invite that this challenge is undertaken.

\section{References}

Acs, Z.J., \& Amorós, J.E. (2008). Entrepreneurship and competitiveness dynamics in Latin America. Small Business Economics, 3, 305-322.

Acs, Z.J., Desai, S., \& Hessels, J. (2008). Entrepreneurship, economic development and institutions. Small Business Economics, 31, 219-234. 
Alstete, J.W. (2002). On becoming an entrepreneur: An evolving typology. International Journal of Entrepreneurial Behaviour and Research, 8(4), 222234.

Amorós, J.E., Basco, R., \& Romaní, G. (2016). Determinants of early internationalization of new firms: the case of Chile. International Entrepreneurship and Management Journal, 12(1), 283-307.

Carland, J.W., Hoy, F., Boulton, W.R., \& Carland, J.A.C. (1984). Differentiating entrepreneurs from small business owners: A conceptualization. Academy of Management Review, 9(2), 354-359.

Casson, M. (2005). Entrepreneurship and the theory of the firm. Journal of Economic Behavior \& Organization, 58, 327-348.

Cheng, H.L., \& Yu, C.M.J. (2008). Institutional pressures and initiation of internationalization: Evidence from Taiwanese small and medium-sized enterprises. International Business Review, 17, 331348.

Deci, E.L., \& Ryan, R.M. (1985). Intrinsic Motivation and Self-Determination in Human Behaviour. New York: Plenum Press.

Dunkelberg, W., Moore, C., Scott, J., \& Stull, W. (2013). Do entrepreneurial goals matter? Resource allocation in new owner-managed firms. Journal of Business Venturing, 28, 225-240.
Lecuna, A., Cohen, B., \& Chavez, R. (2017). Characteristics of high-growth entrepreneurs in Latin America. International Entrepreneurship and Management Journal, 13(1), 141-159.

Liu, A., \& Wall, G. (2006). Planning tourism employment: a developing country perspective. Tourism Management, 27, 159-170.

Madsen, T.K., \& Servais, P. (1997). The internationalization of born globals: An evolutionary process? International Business Review, 6(6), 561583.

McClelland, D.C. (1961). The achieving society. Princeton, NJ: Van Nostrand.

Shane, S., Locke, E.A., \& Collins, C.J. (2003). Entrepreneurial motivation. Human Resource Management Review, 13(2), 257-279.

UNWTO. Barometer of The World Tourism Organization (UNWTO). Retrieved from http://www.unwto.org.

Volchek, D., Saarenketo, S., \& Jantunen, A. (2015). "Structural model of institutional environment influence on international entrepreneurship in emerging economies", In Institutional impacts on firm internationalization, ed. S. Marinova, London, UK: Palgrave MacMillan, pp. 190-216. 